\title{
ANALYSIS OF RELIGIOUS AND PHILOSOPHICAL VIEWS OF CHECHEN SUFI KUNTA-HAJI KISHIEV BASED ON LOCAL ARABOGRAPHIC SOURCES
}

\author{
(C) Muhammad A. Yandarov \\ Russian Islamic Institute, Kazan, Republic of Tatarstan, Russian Federation \\ science-almanac@mail.ru
}

\begin{abstract}
The religious activities of the Chechen Sufi Kunta-Haji Kishiev are revealed. Kunta-Haji expressed his views orally, he sermonized for his followers, demonstrating the practice of performing the ritual associated with the Qadiriyah Tariqa. In Chechnya he became the founder of the Qadiriyah Tariqa. In writing, the teachings of Kunta-Haji are recorded in several arabographic texts which were published in the tsarist period at the beginning of the 20th century in private printing houses in Dagestan. These works were rare, that limited the possibilities of their wide analysis and involvement in scientific circulation. Only in the late 90 s of the 20th century, they began to be published in Arabic and Chechen, that allowed to use them wider, assessing the substantive aspects of the teachings of Kunta-Haji. Ideas calling for peace, condemnation of war, violence, cleansing of sins, spiritual perfection, and the search for a path leading to God are valuable in his teaching.

Key words: Sufi, Chechens, Tariqa, Qadiriyah, Kunta-Haji, Vird (a set of prayers), arabographic texts.
\end{abstract}

\section{[М.А. Яндаров Анализ религиозно-философских воззрений чеченского суфия Кунта-Хаджи Ки- шиева на основе местных арабографических источников]}

Раскрываются религиозная деятельность чеченского суфия Кунта-Хаджи Кишиева. Кунта-Хаджи излагал свои взгляды устно, читал проповеди своим последователям, демонстрируя практику исполнения ритуала, связанного с тарикатом кадирийа, зачинателем которого он стал в Чечне. Письменно учение Кунта-Хаджи зафиксирована в нескольких арабографических текстах, которые были изданы в царский период в начале XX века в частных типографиях Дагестана. Эти работы были редкостью, что ограничивало возможности широкого их анализа и вовлечения в научный оборот. Только в конце $90-\mathrm{x}$ гг. XX века они стали издаваться на арабском и чеченском языках, что позволило шире использовать, оценивая содержательные аспекты учения Кунта-Хаджи. Ценным в его учении являются идеи, призывающие к миру, осуждению войны, насилия, очищению от греховных поступков, духовному совершенству, поиску пути, ведущего к Богу.

Ключевые слова: суфий, чеченцы, тарикат, кадирийа, Кунта-Хаджи, вирд, арабографические тексты.

Muhammad A. Yandarov - Graduate student, Russian Islamic Institute, Kazan, Republic of Tatarstan, Russian Federation.

Яндаров Мохьаммед Андерович - магистрант, Российский исламский институт, г. Казань, Республика Татарстан, Российская Федерация.

Life and religious activity of the Chechen Sufi Kunta-Haji Kishiev is of extremely important spiritual and cultural importance for the Chechens and the Ingush people, as well as some Dagestan peoples. His religious views, statements, instructions, known from the late 50s of the 19th century, are passed from generation to generation. They serve as the basis for spiritual and moral education of younger generations. His spiritual sermons, religious and philosophical statements attracted attention, they were comprehended by military officials, political figures and researchers who recorded his actions, assessed his religious and political activities, the essence of his teachings in different ways.

In this regard, the work of A.P. Ippolitov, an eyewitness who publicized the activities of Kunta-Haji during the beginning of his religious activity, is indicative. He wrote an extensive article about him in tsarist times. This publication reveals: the beginning of Kunta- 
Haji's activities, his social origin, peaceful nature of sermons, politicization of teachings, attraction of thousands of supporters and their defeat [5]. Anti-war philosophy of Sheikh Kunta-Haji is remarkable. Peaceful nature of his sermons was recognized by the commander of the Caucasian army, grand duke M.N. Romanov, who wrote: "...he convinced the people of the need for prayer, labor, mutual assistance and even advised to stop carrying weapons" [10].

In Soviet times, from the point of view of atheism, the activities and teachings of Kunta-Haji were covered in the works of I.A. Makatov [6], M. Mustafinov [7]. This saint himself, revered by the Chechens and the Ingush people, was characterized by atheists as a fanatic, reactionary, obscurantism. These were murderous labels of the religious figure whose life and spiritual teachings are quite comparable to the spiritual searches of L.N. Tolstoy and $M$. Gandhi. At the same time, among the researchers at that time there were those who called for considering the Sufi traditions of the past as the social thought of the peoples of the North Caucasus, including Chechnya and Ingushetia. Among them there is A.D. Yandarov, who made a lot of efforts in developing the teachings of the Caucasian Sufis [10].

In the post-Soviet period, V.H. Akaev engaged in a thorough study of life and religious and philosophical activity of Kunta-Haji Kishiev. He wrote a number of works in which he revealed amazing religious and philosophical teachings of Kunta-Haji in detail [14]. In his research he based on the arabographic text "Tarjamat makalati... Kunta Sheikh," published in 1911 at the Printing House of Mavraev in Temir-han-Shur [2; 3].

The arabographic text "Nokhchiin a, Iarbiin a mattah Ilaskhan-yurtarchu Khyazhin zhain ("The Book of Haji from Ilaskhan-yurt in Chechen and Arabic")" consists of three parts [8]. The first part, translated into Chechen, is called "Zhaina" ("Book"), the second part is called "labdussalama dinachu deita hattarna Ustaza della joipash" ("Kunta-Haji's answers to fourteen questions asked by Abussalam"), the third part consists of KuntaHaji's story about the woman Rabiya Adaviya, the first Sufi woman which fully devoted herself to serving God, there is a letter of Sayyid-Selim, the son of Jamallayla from Mecca, in which he calls on Muslims to honor Kunta-Haji, his teachings and the ziyarat of his mother. In the same part there are Kunta-Haji's speeches and statements set forth in the "Zhaina" part, but with noticeable changes, information about such Chechen sheikhs as G1ezi-sheikh and Tashu-Haji is added, which is absent in it. In this regard, it is scientifically interesting to carry out a comparative analysis of the first and third parts of the arabographic treatise "The Book of Haji from llaskhan-yurt...".

In general, this text presents religious, moral and philosophical views of Kunta-Haji, which were recorded and published by his followers. Their essence is that Kunta-Haji calls on his followers to overcome anger and evil, cleanse the heart of sin, which must be achieved through prayers and the performance of a loud zikr (mention of the name of Allah) $[8, p .13]$. The need to cleanse the heart of ambition, self-interest, is noted in the third part of the source cited [8, p. 53].

During the brutal Caucasian War, addressing the Chechens, he said: "Do not carry a weapon with you, stay away from it. Weapons remind you of violence and take you away from Tariqa. The power of weapons is nothing compared to the power of a person's soul, faithfully walking along Tariqa. Any weapon is a sign of uncertainty that Almighty Allah will come to the aid at the right time. In addition, Iblis constantly pulls your hand to the handle of a dagger or a gun. You become a victim of Iblis."

People's memory also preserved such thoughts of Kunta-Haji: "Your weapon is tasbih, not a gun, not a dagger. Tyrants are powerless against this weapon (tasbih, prayers), for none of the tyrants is stronger than Allah. To die in a battle with the enemy, which is much stronger than you, is like a suicide. A suicide is the worst sin of all sins. Such death is disbelief in the power and mercy of the Most High Allah, who creates tyrants not to 
the detriment, but in the name of cleansing the morality of people, for those who are in Tariqa, tyrants are idols which will fall down and break up like clay pots."

These ideas were new for the brutal 19th century, they were sensitively perceived by highlanders who had fought against the tsarist army for decades, they were tired of war, bloodshed. They gave them psychological calm. It was the personal example of Kunta-Haji and his new concept that played a leading role in the rapid spread of the Qadiriyah Tariqa. It was the illustrative example that had the main psychological effect on the minds of illiterate people. What was the cornerstone of the sheikh's program? In due course, the teacher and mentor of Imam Shamil, Naqshbandian Sheikh Jemaleddin Kazi-Kumukh condemned the first imam, Ghazi-Muhammad, in retreating from one of the principles of Sufism, non-resistance to evil by force, but reliance on God's mercy. Subsequently, he condemned Shamil for the sermon of the holy war, refusing to take part in his plans. Imams were supported only by Sheikh and Murshid Muhammad Yaraginsky, the teacher of Jamaleddin. In 1842, the last in the service of the mosque of the village of Dargo even addressed Shamil with the words: "I strictly forbade you to take up arms against the Russians, but you did not obey me and, perhaps, for your own death, but I advise you to end the war now. If you do not want this, then at least do not forget what I say now: may you be cursed by God and his great prophet if someday you and your murids think of robbing Muslims, at least submissive to the Russians" [10, p. 68].

War and violence in general are given a large layer of philosophical views of KuntaHaji. It was a reasonable and philosophical approach to this problem that was one of those key concepts of the teachings of Kishi-Haji, which provided a wide ethnogeographic field of distribution of his order and vird heirs from Kabardino-Balkaria to Dagestan. The ideology of Kunta-Haji Kishiev was significantly different from the ideology of Imam Shamil and his supporters. In fact, it was the doctrines of Ustaz that was as close as possible to pure Sufism. In European science, this field is incorrectly called "Zikrism," since Zikr (praising God) is also performed by Nakshbandian murids, but they do it without loud singing and rapid body movements. New zikr struck impressionable highlanders with its unusualness and super activity.

According to the first researcher of Qadiriyah and one of the organizers of repressions against the Zikrists A.P. Hippolitov, Kunta-Haji himself did not appeal to the people directly, but used his authorized assistants (vekiley) for these purposes. Thus, Kunta-Haji, it seems to us, tried to avoid possible manifestations of the "cult of personality" and blind worship, from which founders and leaders of new movements and ideologies, from religious to political often suffered. And the fact that during his lifetime he personally engaged in beekeeping on his apiary, without resorting to the work of his murids (although, in case, there would be a lot of people who wanted to), once again speaks in favor of this.

Nevertheless, the instructions transmitted by the sheikh roamed from aul to aul, with various interpretations and comments, not always of a peaceful nature, and sometimes they were completely misrepresented. At the very beginning of its path, the Qadiriyah order in Chechnya did not have a clear organizational structure, and soon, fell into two directions: mystical-ascetic and secular, trying to use new Tariqa to fight the Empire. As a true Sufi, Kishiev could not and did not want to place on himself worldly duties related to politics, and he asked his followers not to do it [10, pp. 140-141].

Another innovation introduced by Kunta-Haji was that it was possible to enter the Qadiriyah Tariqa without personal participation of Ustaz. It was enough to turn to the vekil (assistant) locally, and he conducted a ceremony of initiation. This intelligent and innovative decision contributed to the fact that the brotherhood grew quite quickly. Initially, the teachings of the Qadirians... "at that time were limited to only oral reading prayers, instructions not only harmless, but also very moral, so, in fact, it could be of benefit rather than in any way dangerous." The sermons spoke of the need to help the poor, religious self- 
improvement. The fact that from now on the highlanders will have to live side by side with the Christians, Kishiev called an accomplished fact and urged the Chechens to be tolerant to non-believers [5, pp. 2-3].

However, the new organization attracted not only peaceful citizens, but also radicals, they were angry that the tsarist administration did not keep its promises, and did not return to the Chechens many of their lands transferred to the Cossacks or occupied by fortresses, that the ideas of the holy war were cut in the bud. Someone longed for revenge for dead relatives and comrades. A.P Ippolitov. wrote about this: "Everyone who did not like the existing way of things, all those who felt sorry for the old good time of Shamil, all of them called themselves students and followers of Kunta-Haji, advocates of the Muslim faith, without having the slightest idea of the "Zikr" teachings... They gave the mystical teachings of Kunta-Haji that material and at the same time warlike character, which in essence it did not have at all" [5, p. 3]. After the defeat of the Chechen uprising of 18601861 , the ranks of the Qadirians were replenished with the surviving participants, introducing innovative anti-Russian sentiment into their minds.

Meanwhile, all active force actions by evil for evil, as we have already said above, were categorically rejected by the sheikh. Moreover, his sermons even recommended praying for the offender [5, p. 4]. Let's say more, the sheikh himself called for humility, instructing his followers: if you are forced to wear a cross, wear, this is just iron, if you are forced to go to church, go, these are just walls. However, Kunta-Haji also limited humility. In the case of violence against women, the prohibition of the mother tongue and customs, he urged all the Chechens to rise up as one against tyranny.

For many former murids of Shamil, who fought under the slogan of the holy war, the religious background for the new uprising was a very important reason for resistance and a slogan of their ideology. However, this movement was too young to nominate talented leaders and chiefs in the short time. Meanwhile, the authorities noticed (or were informed of) new developments among the Kuntahajins. And although the sheikh himself opposed anti-Russian performances in every way, the "worldly" wing of the order had been growing steadily.

In 1862-1863, the radical Qadirians began a struggle with the tsarist administration. They killed local officials, soldiers and officers, turning everybody against the order and embittering the authorities and the Russian population of the Terek region. The detachment of Abrek Vara Gekhinsky, who was ultimately killed by the detachment of tsarist troops in Novye Atagi in 1865, was especially different in this matter.

Fearing new rebellions, initially the authorities began to attract orthodox clergy against Kunta-Haji, who in their sermons used the techniques to divide his followers. For example, supporters of the sheikh, ordinary people believed that their Ustaz communicates with God, heals the sick and walks on water like on land. The clergy of the camp of his opponents tried their best to prove to their worshippers the improbability of such phenomena, although Kunta-Haji himself never stated anything like that, understanding the absurdity of such statements.

The reconstruction of the teachings of the Chechen Sufi Kunta-Haji involves a thorough study of the arabographic texts that have become available today, but require adequate translation and interpretation. Ideas calling for peace, condemnation of war, violence, cleansing of sins, spiritual perfection, and the search for a path leading to God are valuable in his teaching.

\section{Лumepamypa}

1. Акаев В.Х. Нравственно-религиозные воззрения шейха Кунта-Хаджи Кишиева // Известия высших учебных заведений. Северо-Кавказский регион. Общественные науки. 1995. № 3. 
2. Акаев В.Х. Религиозно-нравственные воззрения шейха Кунта-Хаджи Кишиева // Из истории ислама в Чечено-Ингушетии. Грозный, 1992. С. 45-51.

3. Акаев В.Х. Шейх Кунта-Хаджи Кишиев в духовной культуре чеченцев: основные вехи жизни, суть учения и современное его значение // Ислам в современном мире. 2016. № 1. С. 95-108.

4. Акаев В.Х. Шейх Кунта-Хаджи: жизнь и учение. Грозный, 1994;

5. Ипполитов А.П. Учение «Зикра» и его последователи в Чечне и Аргунском Округе // Сборник сведений о Кавказских горцах. Вып. II. Тифлис, 1869.

6. Макатов И.А. Религиозные группы Амая и Кунта-Хаджи. Махачкала, 1965.

7. Мустафинов М.М. Зикризм и его социальная сущность. Грозный, 1975.

8. Нохчийн а, Іарбийн а маттахь Иласхан-юртарчу Хьажин жайна (Книга Хаджи из Иласхан-юрта на чеченском и арабском языках). Перевел с арабского на чеченский язык Асхабов Магомед. 5 сентября 1998 г.

9. Яндаров А.Д. Развитие фрилософской и общественно-политической мысли Чечено-Ингушетии в XIX - начале XX века. Авт. дисс. д-ра филос. наук. Алма-Ата, 1986. $40 \mathrm{c}$.

10. Яндаров А.Д. Суфизм и идеология национально-освободительного движения. Алма-Ата, 1975. 176 с.

\section{References}

1. Akaev V.Kh. Nravstvenno-religioznye vozzreniia sheikha Kunta-Khadzhi Kishieva // Izvestiia vysshikh uchebnykh zavedenii [Moral and religious views of Sheikh KuntaHaji Kishiev. Journal of higher educational institutions]. North Caucasus region. Social sciences. 1995. No. 3 (in Russian).

2. Akaev V.Kh. Religiozno-nravstvennye vozzreniia sheikha Kunta-Khadzhi Kishieva. Iz istorii islama v Checheno-Ingushetii [Religious and moral views of Sheikh Kunta-Haji Kishiev. From the history of Islam in Chechen-Ingushetia]. Grozny, 1992. pp. 45-51 (in Russian).

3. Akaev V.Kh. Sheikh Kunta-Khadzhi Kishiev v dukhovnoi kulture chechentsev: osnovnye vekhi zhizni, sut ucheniia i sovremennoe ego znachenie. Islam v sovremennom mire [Sheikh Kunta-Haji Kishiev in the spiritual culture of the Chechens: the main milestones of life, the essence of the teaching and its modern meaning. Islam in the modern world]. 2016. No. 1. pp. 95-108 (in Russian).

4. Akaev V.Kh. Sheikh Kunta-Khadzhi: zhizn i uchenie. [Sheikh Kunta-Haji: life and the teaching]. Grozny, 1994 (in Russian).

5. Ippolitov A.P. Uchenie "Zikra" i ego posledovateli v Chechne i Argunskom Okruge. Sbornik svedenii o Kavkazskikh gortsakh [The teaching "Zikra" and its followers in Chechnya and the Argun District. Collection of information about the Caucasian Highlanders]. Issue II. Tiflis, 1869 (in Russian).

6. Makatov I.A. Religioznye gruppy Amaia i Kunta-Khadzhi [Religious groups of Amai and Kunta-Haji]. Makhachkala, 1965 (in Russian).

7. Mustafinov M.M. Zikrizm i ego sotsialnaia sushchnost [Zikrism and its social essence]. Grozny, 1975 (in Russian).

8. Nokhchiin $a$, Iarbiin a mattah Ilaskhan-yurtarchu Khyazhin zhain (The Book of Haji from Ilaskhan-yurt in Chechen and Arabic). Translated from Arabic into Chechen by Askhabov Magomed. September 5, 1998.

9. Yandarov A.D. Razvitie filosofskoi i obshchestvenno-politicheskoi mysli Checheno- 
Ingushetii $v$ XIX - nachale XX veka [The development of philosophical and sociopolitical thought of Chechen-Ingushetia in the 19th - early 20th centuries]. Dissertation of Ph.D. (Advanced Doctorate) in Philosophy, Alma-Ata, 1986. 40 p. (in Russian).

10. Yandarov A.D. Sufizm i ideologiia natsionalno-osvoboditelnogo dvizheniia [Sufism and ideology of the national liberation movement]. Alma-Ata, 1975. 176 p. (in Russian). 